\title{
Kriz Yönetiminde Reform
}

\author{
Barış ÖVGÜN ${ }^{1}$ ve Hasan GÜL ${ }^{2 *}$
}

Öz

Kriz ve kriz yönetimi sosyal bilimlerin diğer alanlarında olduğu gibi kamu yönetimi alanında da son yıllarda önemi gittikçe artan çalışma alanlarından biridir. Özellikle 1999 Marmara Depremi'nden sonra afet odaklı kriz yönetimi çalışmalarında bir artış olmuş ve kamu yönetimi alanında da kriz yönetimi örgütlenme ve işleyiş boyutlarıyla ele alınmaya başlanmıştır. Bu çalışmaların ortak özelliği kriz olgusunun insan eliyle olmayan doğal afetlerle sınırlı olarak kabul edilmesi ve bu alanın yönetiminin de bu bakış açısıyla sınırlandırılarak afet yönetimi bağlamında değerlendirilmesidir. Oysa kriz, hem doğal olaylardan hem de bizzat insanlar tarafından meydana gelebilmektedir. Bir başka deyişle kriz denilince sadece doğal afetler anlaşılmamalıdır. Ekonomik, toplumsal ve siyasal gelişmelerin yarattığı doğal olmayan afetler de bir kriz halidir. Bu bakış açısıyla uluslararası ve ulusal terör olaylarının yaratmış olduğu güvenlik odaklı sorunlar da önemli bir kriz unsurudurlar. Bu çalışmanın temel tezi ve alan yazındaki diğer çalışmalardan farkı da işte bu noktada ortaya çıkmaktadır. Bu çalışmada kriz, insan eliyle olan ya da olmayan doğal ya da yapay beklenmedik, istenmeyen, ani ve olumsuz olaylar olarak ele alınmakta ve bu olayların kriz olarak yorumlanabilmesi için ekonomik ve toplumsal hayatta önemli tehditler oluşturması aranmaktadır. Kriz kavramını afet odaklı dar çerçevesinden sıyıran bu çalışmada kriz yönetimine de bu tanımlama çerçevesinde yaklaşılmakta ve ekonomik, toplumsal ve siyasal krizleri kucaklayabilecek geniş perspektifli bir kriz yönetim yapısı ve işleyişi önerilmektedir. Çalışmanın kamu yönetimi açısından ilginç sayılabilecek bir özelliği daha bu noktada ortaya çıkmakta ve benimsemiş oldukları farklı hükümet sistemlerine göre seçilmiş ülke örnekleri kriz yönetimi çerçevesinde karşılaştırmalı bir perspektifle incelenerek Türk kamu yönetimi için önerilerde bulunulmaya çalışılmaktadır.

ANAHTAR KELIMELER: Kriz Yönetimi, Reform, Kamu Yönetimi

\section{Reform in Crisis Management}

\begin{abstract}
\footnotetext{
${ }^{1}$ Doç. Dr. , Siyaset Bilimi ve Kamu Yönetimi, Ankara Üniversitesi, Ankara

${ }^{2}$ Uzman, T.C. Cumhurbaşkanlığı, Ankara

*ilgili yazar/ Corresponding Author: hasan.gul @windowslive.com

Gönderim Tarihi / Submission Date: 14.07.2019

Kabul Tarihi / Acception Date: 18.12.2019
}

The crisis and the crisis administration is one of the areas of increasing importance in public administration in recent years as well as in other areas of social sciences. There has been an increase in disaster-oriented crisis administration studies, especially after the 1999 Marmara Earthquake and the crisis administration has been tried to be dealt with in terms of organization and operation in the field of public administration. The common feature of these studies is to deal with the crisis phenomenon limited to natural disasters without human 
hand and the administration of this area is also limited in this perspective and evaluated in the context of disaster administration. However, the crisis can occur both by natural events and by people themselves. In other words the crises are also created by human or the natural disasters should not be understood when the crisis is called. The unnatural disasters created by economic, social and political developments are also a crisis. Security-oriented problems created by international and national terrorist incidents are also an important element of crisis. The main thesis of this paper and its differences from the other studies in the literature are emerging at this point. In this study, the crisis is considered as natural or artificial (by human or non-human), unexpected, unwanted, sudden adverse events and they must pose significant threats to economic and social life in order to interpret these events as crises. In this study, the crisis administration is also approached within the framework of this definition and a wide-ranging crisis administration structure and operation that embraces economic, social and political crises is recommended. There is another interesting feature of the study in terms of public administration: The examples of selected countries according to the different governmental systems they have adopted are examined from a comparative perspective within the framework of crisis administration and suggestions are made for Turkish public administration.

KEYWORDS: Crisis Management, Reform, Public Administration

\section{GiRiş}

Kamu yönetimi ekonomik, toplumsal ve politik gereksinimler doğrultusunda sürekli reforma tabi tutulmaktadır. Kamu yönetiminin örgütlenmesi ve işleyişinde yaşanan bu reform sürecinin en önemli alanlarından biri de krizdir. Kamu yönetiminde kriz anlayışının ne olduğuna yönelik alanyazın genel bir değerlendirmeye tabi tutulduğunda kamu yönetiminin daha çok örgüt/idare odaklı ele alındığı ve krizin de her türlü olağanüstü gelişme olarak tanımlanmasının sonucu olarak kamu yönetiminin örgüt odaklı refleksleri konu alınmaktadır. Özellikle doğa olayları inceleme nesnesi olarak ele alınmakta ve doğal afetlerin olmasından önce ve sonra kamu yönetiminin yapısal ve işlevsel durumu sorgulanmaktadır. Oysa kriz ve kriz yönetimi sadece doğa olaylarıyla sınırlandırılmaması gereken bir alandır. Bu bakış açısıyla bu çalışmada kriz olgusuna daha geniş kapsamlı bir bakış açısı sergilenerek kriz, insan eliyle olan ya da olmayan ani ve istenmeyen olaylar olarak tanımlanarak kriz yönetiminin bu olayları nasıl kontrol etmesi gerektiği üzerinde durulmaktadır.

Kriz kavramını kendisine odak olarak alan çalışmalar genel bir değerlendirmeye tabi tutulduğunda üzerinde uzlaşılmış evrensel bir kriz tanımının olmadığı dikkat çekmektedir (Ritchie vd, 2011). Krize ilişkin çok sayıda tanım bulunmakla birlikte bu tanımların ortak özelliği beklenilmeyen ve ani bir şekilde gerçekleşen ve mevcut durumu istenmeyen şekilde bozabilecek olumsuz durumlardır (Nakip vd, 2001:115 \& Demirtaş ve Güneş, 2002:97-98). Bir başka deyişle kriz kavramı, zor durumu, istenilmeyen bir anı, buhranı ve güçlüğü işaret etmektedir.

$\mathrm{Bu}$ tanımların ortak özelliği krizlerin ekonomik, toplumsal, fiziksel ve hatta psikolojik nedenlerinin olabileceğidir. Bu bağlamda kriz, afet, terör olayları, büyük ekonomik buhranlar ya da teknolojik sorunlar gibi çok geniş bir faaliyet alanına sahiptir (Akdağ, 2002:6). Başbakanlık kriz yönetim merkezi yönetmeliğinde geçen kriz hali tanımı da bu ortaklık üzerine kurulmuştur: (RGT: 09.01.1997, 22872)

Kriz hali; devletin ve milletin bölünmez bütünlüğü ile milli hedef ve menfaatlerine yönelik hasmane tutum ve davranışların, Anayasa ile kurulan hür demokrasi düzenini veya hak ve hürriyetlerini ortadan kaldırmaya yönelik şiddet hareketlerinin, 
tabi afetlerin, tehlikeli ve salgın hastalıkların, büyük yangınların, radyasyon ve hava kirliliği gibi önemli nitelikteki kimyasal ve teknolojik olayların, ağır ekonomik bunalımların ve iltica ve büyük nüfus hareketlerinin ayrı ayrı veya birlikte vuku bulduğu halleri ifade eder.

Bu doğrultuda kriz, barışta veya normal şartlarda ülkenin ulusal güvenlik ve çıkarlarını, siyasal, sosyal ve ekonomik yaşamını olumsuz yönde etkileyebilecek, tehlikeye sokabilecek, aniden ortaya çıkan beklenmedik durum ve olaylar ile başlayarak, silahlı çatışmaya kadar tırmanan, müteakiben barış durumuna ve normal şartlara dönülmesine kadar uzanan bir süreç olarak tanımlanabilir (Yılmaz ve Gül, 2017). Bu tanımlardan da anlaşılacağı üzere kriz sadece afet odaklı bir içeriğe sahip değildir. Afetler kadar önemli olan ya da olması gereken ekonomik, toplumsal ve politik unsurlara sahiptir. Tanımın bu şekilde genişlemesi ve afetlerden ekonomik sıkıntılara, toplumsal kargaşalardan terör olaylarına kadar geniş bir yelpazeye ulaşması önemlidir. Örneğin kriz çalışmalarında kendisine pek bir yer bulamamış olan darbe girişimi ya da darbeler de aslında önemli kriz örnekleridir. Çünkü askeri müdahalelerin tümü siyasi, idari ve toplumsal yapının olağan seyri dışında gelişen, olağan dışı ve kamu hizmeti sunumunu kesintiye uğratan olaylardır (Genç, 2017: 223). Bu unsurların kriz olgusunu yaratabilmeleri için maddi ve manevi zarar doğurması gerekmektedir. Bir başka deyişle doğal afetler ya da büyük kazalardan veya olaylardan kaynaklı hasarlar ya da özellikle güvenlik kaynaklı olayların doğurduğu korku ve endişe durumları söz konusu olmalıdır. Çünkü krizler ani süreli ortaya çıkan ve içinde çeşitli sürprizleri barındıran süreçlerdir (Hermann, 1969). Sonuç olarak, meydana gelen bir krizin genel özellikleri şunlardır:

(1) Genellikle beklenmeyen bir durumdur.

(2) Daha önce olmamıştır, başka bir krizle kıyaslanamaz.

(3) Kontrolü zordur.

(4) Genellikle çok karmaşıktır.

(6) Muhtemelen şiddet artma eğilimindedir.

(8) Zaman sınırlıdır.

(9) Bilgi çok ama doğru değildir.

(10) Söylentiler ve spekülasyonlar ayıklanmalıdır (Yılmaz ve Gül, 2017).

\section{Kriz Yönetimi}

Tarih boyunca ülkelerin sivil ve asker yöneticileri, belirsizlikleri azaltacak ve karar almada önemli avantajlar sağlayacak bilgilerden yararlanmak suretiyle, tehlikeler konusunda önceden uyarılmaya ve hazırlıklı olmaya önem vermişlerdir. Devlet adamı sadece günlük olaylarla, sorunlarla uğraşmaz, ileride ortaya çıkabilecek gelişmeleri, sorunları tahmin ederek çeşitli olasılıklara göre çözüm önerileri de hazırlar (Yılmaz ve Gül, 2017). Ülkeler, devam eden ve muhtemel krizleri ve yeni oluşumları yakından takip ederek, ulusal güvenliğe ve çıkarlara gelecek tehdit ve riskleri önceden değerlendirmek, gerekli önlemleri önceden almak ve ulusal güç unsurlarının imkânları dâhilinde inisiyatifli bir politika izlemek zorundadırlar. Çünkü Aykaç'ın da ifadesi ile kriz özel bir durumdur ve özel bir yönetim biçimi gerektirir (Aykaç, 2001: 2). Devletin güç ve kaynakları ulusal çıkarlar doğrultusunda kullanılırken iyi düşünülmüş, hazırlıklı, tüm aktörler ve vasıtaları entegre eden bir kriz yönetim sistemine intiyaç bulunmaktadır.

Fink'e göre kriz yönetimi kendi kaderiniz üzerinde daha fazla kontrol sahibi olmanızı sağlamak için risk ve belirsizliğin ortadan kaldırma sanatıdır. Ayrıca, kriz olumlu ya da olumsuz olabilen belirleyici bir değişimin yaşanacağı kararsız bir zamandır (Fink, 1986). Öte 
yandan, Glaesser'e göre kriz yönetimi, krizi önlemek ve bunlarla başa çıkmak için planlanan ve uygulanan stratejiler, süreçler ve önlemler olarak anlaşılmaktadır (Glaesser, 2006). Krizlerin olmasını önlemek kadar oluşan krizleri bertaraf etmek de önemlidir. Bu nedenle krizlere hızlı bir şekilde müdahale etmek ve bu müdahaleyi de en etkin şekilde yapmak önemlidir. Çünkü kriz, Tekin'in de belirttiği üzere örgütlerin çevrede meydana gelen değişimlere uyum sağlayamamasından dolayı gündelik işleyişin ve mevcut yapının bozulmaya başladığı, yönetimin karar almakta zorlandığı ve bu nedenle de hızlı karar almanın önemli olduğu bir süreç halidir (Tekin, 2016:122). Kriz dönemlerinde krize mağdur kalan herkes en gerçekçi bilgilere ulaşmak istemektedir. Bu nedenle bilgilerin parça parça değil; gerçekçi veriler olması gerekmektedir. Bilgiler ne kadar gerçek olursa vatandaşların yönetime güvenleri de o kadar fazla olur. Ayrıca bu verileri kimin verdiği de oldukça önem taşımaktadır. Çünkü idari kararsızlık da var olan krizin artmasına ya da yeni bir krizin doğmasına neden olabilecektir (Göksu, 2011).

Bu bağlamda kriz yöntemi sadece krizler sonrasında değil; kriz olmadan önce de ortaya çıkan ve krizlerin olma olasılığını azaltan ya da olması durumunda en az zararla bu durumdan kurtulmayı sağlayan süreçler toplamıdır (Boin, 2004:168). Kriz yönetimi kontrol edilemeyen ve beklenmedik kamu zararının doğduğu anda, öncesinde ve sonrasında, hükümetler, yerel yönetimler ve gönüllü kuruluşlar tarafından gerçekleştirilen kurtarma, zararları azaltma ve hazırlık olarak tanımlanabilir (Smith, 2006). Agustine'nin geliştirmiş olduğu kriz yönetim modeline göre kriz yönetiminin altı safhası vardır (Yılmaz ve Gül, 2017). Bu safhalar sırasıyla şöyledir: (i) Krizden kaçınmak, (ii) Kriz yönetimi için hazırlık yapmak, (iii) Krizi tanımak, (iv) Krizin içeriğini anlamak, (v) Krizi çözüme kavuşturmak ve (vi) Krizden ders almak.

Bu yaklaşımlarla birlikte kriz yönetimi, kriz durumunun teşhisinden başlayarak, kriz sürecini yönlendirmek için kararların alınmasını, alınan kararların uygulanmasını, bu sürecin takip ve kontrol edilmesini içeren faaliyetler serisidir (Yılmaz ve Gül, 2017). Buna ek olarak, kriz yönetim sürecinin temel aşamaları aşağıdaki unsurlardan oluşmaktadır:

i. $\quad$ Bilgi toplayarak durumun analiz edilmesi (durum farkındalığı)

ii. $\quad$ Ulaşllacak hedeflerin ve seçeneklerin tespit edilmesi

iii. Seçeneklerin içinden en uygun olanın uygulanması

iv. Döngüyü geri besleme ile devam ettirmek

Tüm bu sürecin ise zaman baskısı altında yapıldığı unutulmamalıdır (Yılmaz ve Gül, 2017). Çünkü örgütler kriz içerisinde olduklarını çeşitli nedenlerle anlamayabilirler. Eğer kriz anında hızı karar verilemiyorsa ve örgüt içerisinde iletişim kopuk ya da yetersizse örgütler kriz içerisinde olduklarını ya anlamazlar ya da çok geç farkına varırlar (Genç, 2017:224). Geç farkına varma ise örgütün kriz içerisine girmesine ve istenmeyen sorunlarla karşılaşmasına neden olabilecektir. Bu nedenle kriz yönetimi, sadece kriz sonrasını değil; kriz anını ve hatta öncesini kapsayan üç evreli bir süreçtir.

Farklı hükümet sistemlerini benimsemiş olan ülkelerin yönetim örgütlenmeleri ve işleyişleri de buna göre değişebilmektedir. Bu çalışmada da farklı hükümet sistemlerini benimsemiş olan ülkeler kriz yönetimi çerçevesinde analiz edilmeye çalışılmaktadır. Bu çerçevede seçilen örneklerle kriz merkezlerinin yapısı, misyonu, değerlendirmeleri, faaliyetleri ve ürünleri doğrultusunda bir tablo oluşturulmuştur. 
Tablo1: Dünyada Kriz Merkezi Odalarının Yapısı, Misyonu, Faaliyeti ve Ürünleri (Manchin, 2014; Yılmaz ve Gül, 2017)

\begin{tabular}{|c|c|c|c|c|c|}
\hline $\begin{array}{l}\text { ÜLK } \\
\mathrm{E}\end{array}$ & $\begin{array}{c}\text { KURULUŞ } \\
\text { ISMI }\end{array}$ & YAPISI & MISYONU & DEĞERLENDIRMELER & $\begin{array}{l}\text { FAALIYETLERII/ } \\
\text { ÜRÜNLERİ }\end{array}$ \\
\hline 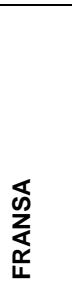 & $\begin{array}{l}\text { Kriz Merkezi } \\
\text { Crisis Center } \\
\text { (CC) }\end{array}$ & $\begin{array}{l}\text { Dışişleri Bakanlığı, } \\
\text { Bakanın } \\
\text { yönetimindedir (2008). }\end{array}$ & $\begin{array}{l}\text { Risk ve tehditlerin izlenmesi, } \\
\text { İnsani krizleri yönetmek ve } \\
\text { müdahale edilmesidir. } \\
\text { Müdahahale planları ve } \\
\text { senaryolar hazırlanması ve sivil } \\
\text { toplum kuruluşları, uluslararası } \\
\text { kuruluşlar ve hükümetin } \\
\text { koordine edilmesidir. }\end{array}$ & $\begin{array}{l}\text { Hem insan eliyle } \\
\text { meydana gelen krizleri, } \\
\text { hem de doğal krizleri ve } \\
\text { felaketlerin analizinin } \\
\text { hazırlanmasını } \\
\text { içermektedir. }\end{array}$ & $\begin{array}{l}\text { Ortaya çıkan krizler ve } \\
\text { devam eden krizler hakkında } \\
\text { ilave raporlar ve durum } \\
\text { güncellemeleri ile ilgili olarak } \\
\text { iki günlük özet } \\
\text { hazırlanmasıdır. Ayrıca, } \\
\text { sürekli izleme ve analiz } \\
\text { yapılmasıdır. }\end{array}$ \\
\hline 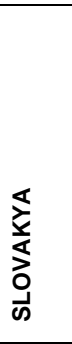 & $\begin{array}{l}\text { Kriz Yönetimi } \\
\text { Bölümü } \\
\text { Crisis } \\
\text { Management } \\
\text { Department } \\
\text { (CMD) }\end{array}$ & $\begin{array}{l}\text { Dışişleri Bakanlığı, } \\
\text { Bakanın } \\
\text { yönetimindedir (2009). } \\
4 \text { kişilik kadroya } \\
\text { sahiptir. Hükümet, } \\
\text { İçişleri Bakanlığı ve } \\
\text { Savunma Bakanlığı } \\
\text { bünyesindeki diğer } \\
\text { kriz odaları ve durum } \\
\text { merkezleriyle yakın } \\
\text { işbirliği içinde } \\
\text { çalışmaktadır. }\end{array}$ & $\begin{array}{l}\text { Görevi Bakana güncellenmiş } \\
\text { veri analizlerinin ve olayların } \\
\text { izlenmesini içermektedir. } \\
\text { Büyükelçiliklerin kriz } \\
\text { zamanlarında desteklenmesi ve } \\
\text { Bakanlıkta sivil savunmamın } \\
\text { sağlanması yer almaktadır. } \\
\text { Seyahat önerileri } \\
\text { düzenlemekten ve yurtdışındaki } \\
\text { vatandaşlara sms hizmeti } \\
\text { vermekten sorumludur. }\end{array}$ & $\begin{array}{l}\text { Potansiyel risk } \\
\text { kaynakları hakkında } \\
\text { incelemeler yapar ve } \\
\text { risk analizini Bakan'a } \\
\text { gönderir. }\end{array}$ & $\begin{array}{l}\text { Risk değerlendirmesi ve risk } \\
\text { profilleri sağlayacak bir 'Risk } \\
\text { Yönetim Portalı' oluşturmaya } \\
\text { çalışmaktadır. Ayrıca, hem } \\
\text { insan kaynaklı hem de doğal } \\
\text { tehditler üzerinde hafifletme } \\
\text { tedbirleri ve kriz yönetimi } \\
\text { desteği konusunda tavsiye ve } \\
\text { analiz sağlamaktadır. }\end{array}$ \\
\hline 包 & $\begin{array}{l}\text { Kriz Yönetim } \\
\text { Koordinasyon } \\
\text { Sekreterliği } \\
\text { Crisis } \\
\text { Management } \\
\text { Coordination } \\
\text { Secretariat } \\
\text { (CMCS) }\end{array}$ & $\begin{array}{l}\text { Başbakanlık Ofisi } \\
\text { yönetimi altındadır. }\end{array}$ & $\begin{array}{l}\text { Bilgileri toplanması, } \\
\text { değerlendirilmesi, analiz } \\
\text { edilmesi ve erken uyarı } \\
\text { incelemelerinin hazırlanmasıdır. } \\
\\
\text { İsveç hükümetinin krizlere } \\
\text { tepkisinin iyi hazırlanmış, etkili } \\
\text { ve zamanlı olmasının } \\
\text { sağlamasında görev } \\
\text { yapmaktadır. }\end{array}$ & $\begin{array}{l}\text { Erken uyarı analizleri } \\
\text { hazırlayıp, potansiyel } \\
\text { tehditleri ve krizleri } \\
\text { izlemektedir. } \\
\text { Sistematik olarak } \\
\text { niceliksel analiz } \\
\text { yapmaz, ancak diğer } \\
\text { bölümler tarafından } \\
\text { hazırlanan nicel ve nitel } \\
\text { raporlara ve analizlere } \\
\text { erişebilmektedir. }\end{array}$ & $\begin{array}{l}\text { Düzenli olarak sunulan } \\
\text { günlük ve haftalık analitik } \\
\text { ürünlerin yanı sıra, diğer } \\
\text { istihbarat raporlarını da } \\
\text { üretmektedir. Bu raporlarda, } \\
\text { eylem önerisi standart } \\
\text { değildir, ancak dâhil edilebilir. } \\
\text { Sekreterlik tarafından } \\
\text { hazırlanan bilgi ve analizler } \\
\text { Bakanlar Kurulu'na } \\
\text { sunulmaktadır. }\end{array}$ \\
\hline 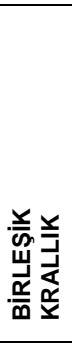 & $\begin{array}{l}\text { Sivil } \\
\text { Beklenmeyen } \\
\text { Olay } \\
\text { Sekreterliği } \\
\text { Civil } \\
\text { Contingenci } \\
\text { es } \\
\text { Secretariat } \\
\text { (CCS) }\end{array}$ & $\begin{array}{l}\text { İçişleri Bakanlığı, } \\
\text { Güvenlik ve İstihbarat } \\
\text { Koordinatörü } \\
\text { yönetiminde ve } \\
\text { Kabine Ofisi içinde yer } \\
\text { almaktadır. Ulusal, } \\
\text { bölgesel ve yerel } \\
\text { düzeylerde, kamu, } \\
\text { özel ve sivil kesimler } \\
\text { üzerinde } \\
\text { çalışmaktadır. }\end{array}$ & $\begin{array}{l}\text { Ulusal krizlere müdahalenin } \\
\text { planlanması ile krizlere hazırlık } \\
\text { ve müdahaleyi yönetmekten } \\
\text { sorumludur. }\end{array}$ & $\begin{array}{l}\text { Veri toplamak için } \\
\text { sınıflandırılmış ve } \\
\text { sınıflandırılmamış bilgi } \\
\text { sistemlerini kullanarak } \\
\text { çoğunlukla nitel analiz } \\
\text { yapmaktadır. } \\
\text { Sosyal medya izlemesi } \\
\text { yapmaktadır. } \\
\text { Hükümetin diğer } \\
\text { birimlerinden gelen } \\
\text { analiz ve bilgilerden de } \\
\text { faydalanmaktadır }\end{array}$ & $\begin{array}{l}\text { Kısa dönem analizler olmak } \\
\text { üzere (en fazla } 6 \text { ay) tehlike, } \\
\text { kriz ve felaketler için risk } \\
\text { değerlendirmesi, hazırlık ve } \\
\text { planlama yapmaktadır. Uzun } \\
\text { vadeli analiz (en fazla } 20 \text { yıl) } \\
\text { eğilimlerine odaklanmaktadır. } \\
\text { Krizlere milli müdahaleyi } \\
\text { organize etmektedir. }\end{array}$ \\
\hline 䍃岂 & $\begin{array}{l}\text { Devlet } \\
\text { Operasyon } \\
\text { Merkezi } \\
\text { Departmanı } \\
\text { Department } \\
\text { of State } \\
\text { Operation } \\
\text { Centre } \\
\text { (OC) }\end{array}$ & $\begin{array}{l}\text { Dışişleri Bakanın } \\
\text { yönetimindedir (1961). } \\
\text { İzleme (7/24) ve Kriz } \\
\text { Yönetimi Destek Ekibi } \\
\text { olmak üzere iki } \\
\text { bölümden } \\
\text { oluşmaktadır. }\end{array}$ & $\begin{array}{l}\text { Uluslararası ve ulusal aktörler } \\
\text { arasındaki iletişimi } \\
\text { kolaylaştırmaktan sorumludur. } \\
\text { Dışişleri Bakanlığı'nın doğal } \\
\text { felaketler, terörizm, sosyal } \\
\text { kargaşa, uygulanan } \\
\text { politikalardaki ani değişiklikler } \\
\text { vb. kriz durumlarına verdiği } \\
\text { cevabı organize etmek için, } \\
\text { Başkanı bilgilendirmek üzere } \\
\text { Dışişleri Bakanına en yeni ve } \\
\text { en iyi kaynaklı bilgileri } \\
\text { sağlamaktır. }\end{array}$ & $\begin{array}{l}\text { Çoğunlukla nitel analiz } \\
\text { yapar ve açık kaynaklar } \\
\text { (medya, sosyal medya } \\
\text { ve ikincil analiz) ile } \\
\text { devletin diğer } \\
\text { kurumlarının bilgileri de } \\
\text { dâhil olmak üzere çeşitli } \\
\text { kaynaklardan yararlanır. }\end{array}$ & $\begin{array}{l}\text { Dışişleri Bakanı için durum } \\
\text { raporları ve gerekirse özel } \\
\text { bilgilendirme için iki günlük } \\
\text { bilgilendirme arzı } \\
\text { hazırlamaktadır. OC, Dışişleri } \\
\text { Bakanlığı'nın ilgili birimleri, } \\
\text { elçilikler, konsolosluklar ile } \\
\text { Dışişleri Bakanı'nın dış } \\
\text { politika yapmak için temasa } \\
\text { geçmesi gereken yabancı } \\
\text { aktörleri bir araya getiren bir } \\
\text { iletişim merkezi olarak hizmet } \\
\text { etmektedir. }\end{array}$ \\
\hline
\end{tabular}

\section{Dünya kriz merkezi örnekleri incelendiğinde aşağıdaki sonuçlara ulaşılmıştır:}

i. Dünyadaki örneklere bakıldığında, kriz merkezleri (durum merkezi), üst düzey yönetici seviyesinde temsil edilmekte ve yönetilmektedir.

ii. Kriz merkezi, günlük bilgi arzının yanı sıra haftalık, aylık ve yıllık olarak nitel ve nicel yöntemlerle analiz edilen olayları ilgili makamlara raporlayarak sunmaktadır.

iii. Bu raporlar senaryo, risk, tehdit ve fırsat değerlendirmelerini içermektedir. 
iv. Yapılan değerlendirmeler, olası siyasi, ekonomik ve/veya toplumsal kriz durumları hakkında ülkenin çıkarları ve öncelikleri doğrultusunda; kısa, orta ve uzun vadeli strateji ve planlamaları kapsamaktadır.

v. Kriz (durum) merkezlerinden, insan eliyle veya doğal yollardan meydana gelen felaketlerin yönetilmesi ve müdahalesinde, koordinasyonun sağlanmasının yanı sıra, politika üretilmesine yardımcı olunması da beklenilmektedir.

vi. Kriz merkezleri, sosyal medya, internet kaynakları, medya ve benzeri açık kaynaklardan ve istihbarat raporları, ilgili bakanlık raporları gibi gizli kaynaklardan da yararlanmaktadır.

vii. Kriz merkezleri, 7 gün 24 saat aktif olarak faaliyetlerini sürdürmektedir. Yapılan işlerle doğru orantılı olarak farklı alanlarda uzman personel çalıştırılmaktadır.

\section{Türkiye'deki Mevcut Durum}

Ülkemizde kriz yönetimi kapsamında oluşturulmuş birçok kurumsal yapı bulunmaktadır. Bu yapılar bünyesinde farklı kriz alanlarına odaklanılmıştır. Bu alanlar, temel olarak askeri ve sivil alanlar olarak sınıflandırılabilir. Bu kurum ve kuruluşların odak noktaları ise güvenlikten, toplumsal olaylara, doğal afetlerden, sağlık ve dijital dünyaya kadar uzanmaktadır. Türkiye'deki Kriz merkezleriyle ilgili mevcut durumun anlaşılması için açık kaynaklar kullanılarak Türkiye'de Kriz/ Koordinasyon/ Harekât Merkezine sahip Kurum ve Kuruluşlar isimleri ve çalışma şekilleri Tablo 2'de gösterilmiştir:

Tablo 2: Türkiye'de Kriz/ Koordinasyon/ Harekât Merkezine sahip Kurum ve Kuruluşları

\begin{tabular}{|c|c|}
\hline Kurum/Kuruluş İsmi & Çalışma Şekli \\
\hline $\begin{array}{c}\text { Cumhurbaşkanlığı Güvenlik İşleri Genel Müdürlüğg̈ Devlet Bilgi } \\
\text { Koordinasyon Merkezi Daire Başkanlığı }\end{array}$ & 7 gün /24 saat \\
\hline Milli Güvenlik Kurulu Genel Sekreterliği Kriz Merkezi & 7 gün /24 saat \\
\hline $\begin{array}{l}\text { Genel Kurmay Başkanlığı Silahlı Kuvvetler Komuta Harekât Merkezi } \\
\text { (SKKHM) }\end{array}$ & 7 gün /24 saat \\
\hline Jandarma Genel Komutanlığı Harekât Merkezi & 7 gün /24 saat \\
\hline Sahil Güvenlik Komutanlığı Harekât Merkezi & 7 gün /24 saat \\
\hline Emniyet Genel Müdürlüğü Koordinasyon Daire Başkanlığı & 7 gün /24 saat \\
\hline $\begin{array}{c}\text { İçişleri Bakanlığı Afet ve Acil Durum Yönetimi Başkanlığı Afet ve Acil } \\
\text { Durum Yönetim Merkezi(AFAD) }\end{array}$ & 7 gün /24 saat \\
\hline İçişleri Bakanlığı Güvenlik ve Acil Durum Koordinasyon Merkezi(GAMER) & 7 gün /24 saat \\
\hline Kızılay Afet Operasyon Merkezi (AFOM) & 7 gün /24 saat \\
\hline Sağlık Bakanlığı Sağlık Afet Koordinasyon Merkezi(SAKOM) & 7 gün /24 saat \\
\hline $\begin{array}{c}\text { Bilgi Teknolojileri ve İletişim Kurumu Ulusal Siber Olaylara Müdahale } \\
\text { Merkezi (USOM) }\end{array}$ & 7 gün /24 saat \\
\hline
\end{tabular}

Kriz yönetiminin örgütlenmesine ve işleyişine bakıldığında Türkiye'de tüm kriz çeşitleriyle görevli bir tek kurum ya da kuruluşun olmadığı ve farklı teşkilatların farklı veya benzer konularda görevli olduğu görülmektedir (Göksu, 2011: 37). Günümüzde ihtiyaç duyulan kriz yönetimi, sivil ve askeri unsurlar ve imkânlarını uyumlu bir stratejide birleştiren kriz yönetimine bütüncül bir yaklaşımdır. Kriz yönetiminde birleşme, tek çatı altında bulunma 
etkililik ve verimlilik açısından gereklidir (Göksu, 2011:37). Dolayısıyla, kriz yönetiminin tüm seviyelerinde eşgüdümlü çaba gösterilmelidir. Ayrıca, etkili bir koordinasyon stratejisinin önemli unsurları arasında ortak terminolojinin oluşturulması, uzman grupların ve ağların kurulması, koordinasyon ve müşterek bir noktanın tanımlanması yer almaktadır (Doktor, 2007). Türkiye'de kriz yönetimi ve kriz merkezleri ile ilgili bütüncül bir bakış açısıyla yeniden bir değerlendirmenin yapılması gerekmektedir. Çünkü günümüzde krizlerin içeriği ve meydana gelme nedenleri, kriz yönetimine bütüncül bir yaklaşımla bakılması intiyacını doğurmaktadır (Doktor, 2007).

Dolayısıyla, Türkiye'de kriz ve kriz yönetimi ile ilgili kurulan farklı kurum ve kuruluşlar bulunmaktadır. Ancak bu kurum ve kuruluşlar arasında koordinasyon ve işbirliğini sağlayacak tek bir üst yapı henüz tesis edilmemiştir. Bu uyum ve işbirliğinin olmaması, farklı sorunlara neden olmaktadır. Örneğin, insan kaynağından yeterince faydalanılmamasına, tesis, alt yapı, teknoloji gibi maddi olanaklarından yeterince yararlanılamamasına neden olmaktadır. Bu kaynakların verimli kullanılamaması ise, kriz yönetiminde ortak bir hafızanın oluşmasına ve kriz yönetimi kültürünün yerleşmesine engel olmaktadır. Meydana gelen hükümet sistemi değişikliği neticesinde, kriz yönetimi alanında da yeni sistemle (Cumhurbaşkanlığı Hükümet Sistemi) uyumlu bir dönüşüm ve yeniliğin sağlanması gerekmektedir.

\section{Sonuç Yerine}

Türkiye'de kriz yönetimi bağlamında aşağıdaki öneriler değerlendirilmelidir. Kriz yönetiminin değişim ve dönüşüme dolayısıyla reforma tabi tutulması gerekmektedir. Bu reform kapsamında:

i. Kriz yönetimi için bütünleyici bir yaklaşımla, krizin tüm safhalarına müdahil olacak bir yaklaşım sergilenmelidir. Böylece, mümkün ve gerekli olduğunda, krizleri önlemek ve yönetmek, çatışma sonrası durumları istikrara kavuşturmak ve yeniden inşa etmek için müdahil olunacaktır.

ii. Kriz yönetimi içinde çok sayıda aktörün katıımı ve faaliyetlerinin koordinesi yanında pek çok geniş alanda vasıtaların kullanılması göz önüne alınmalıdır.

iii. Krizlere geniş kapsamlı ve kapsayıcı bir yaklaşım sağlamak için sivil ve askeri faaliyetlerin yanında yerel unsurların eğitimi ve geliştirilmesi de önemlidir.

iv. Kriz yönetimi kapasitesi, gerçek zamanlı ve sürekli, her türlü krize karşılık verecek güçlü ve az bulunur siyasi ve askeri kabiliyetlere sahip olmalıdır.

v. Kriz yönetimi kapasitesi için ülke güvenliğini etkileyebilecek potansiyel krizlere yönelik uygun siyasi ve askeri vasıtalar geliştirilmelidir. Böylece, krizlerin tırmanmadan önlenmesi, devam eden çatışmaların durdurulması ve çatışma sonrası istikrarın geliştirilmesi sağlanabilir.

Kriz yönetimi, ülkenin geleceği ile ilgili tehditleri ve fırsatları önceden görmeyi ve hazırlıklı olmayı gerektirir. Bu amaçla, karar verici ve politika yapıcılara zamanında ve doğru öngörülerde bulunacak bir 'kriz yönetimi kariyer meslek personeli' varlığı gerekmektedir. Cumhurbaşkanlığı himayesinde, Güvenlik ve Dış Politikalar Kurulu, MGK Genel Sekreterliği, Genelkurmay Başkanlığı, Güvenlik İşleri Genel Müdürlüğü ile sivil toplum kuruluşlarını temsilen üniversiteler, araştırma merkezleri, düşünce kuruluşları gibi organizasyonlardan görevlendirilecek düşünce insanları, uzmanlar, analizciler, saha elemanları ile geniş bir kriz yönetimi insan kaynağı oluşturulmalıdır. 


\section{Kaynaklar}

Akdağ, E. (2002). Mali Yapı ve Denetim Boyutlarıyla Afet Yönetimi. Araştırma/İnceleme/ Çeviri Dizisi: 20, Ankara: Sayıştay Yayın Dışişleri Müdürlüğü Yayınları

Augustine, N.R. (1995). Managing the Crisis You Tried to Prevent. Harvard Business Review. Boston: HBR

Aykaç, B. (2001). Kamu yönetiminde kriz ve kriz yönetimi, Gazi Üniversitesi ï̈BF Dergisi, 123-132.

Başbakanlık kriz yönetim merkezi yönetmeliği, (RGT: 09.01.1997, 22872)

Boin, A., (2004). Lessons From Crisis Research. Managing Crises in The Twenty-First Century, (Ed.) B. W. Dayton, (165-194). International Studies Review, 6.

Dayton W. Bruce (2009). Crisis Management. Moynihan Institute of Global Affairs, Syracuse University Prepared for the International Encyclopedia of Peace Oxford University Press.

Demirtaş, H. ve Güneş H., (2002). Kriz. Eğitim Yönetimi ve Denetimi Sözlügüu, Ankara: Anı Yayıncılık, s. 97-98.

Doktor. C (2007) "Strategic Crisis Management:Trends And Concepts" Center For Security Studies (November 2007), Vol.2 No.23,1-3.

Fink, S. (1986). Crisis management: Planning for the inevitable. New York, NY: American Management Association.

Genç, F. N. (2017). Türkiye'de Askeri Müdahaleler ve Kriz Yönetimi. Electronic Turkish Studies, 12(16), 219-240.

Glaesser, D. (2006). Crisis management in the tourism industry. Oxford, UK: Routledge.

Göksu, T. (2011). Kamuda Kriz Yönetimi ve Türkiye'de Kriz Yönetimi Teşkilatlanması. Türk İdare Dergisi 459, 37-64.

Hermann, F. Charles. (1969). "International Crisis as a Situational Variable" ,In International Politics and Foreign Policy, edited by James Rosenau. New York: Free Press.Vol.2, 409421.

Korkmazyürek, H., Basım, H. N. (2009). İş modeli ve kriz yönetimi. Ankara: Siyasal Kitapevi, s.14.

Lægreid, P., \& Rykkja, L. H. (Eds.). (2018). Societal Security and Crisis Management: Governance Capacity and Legitimacy. Springer.

Manchin, J. (2014). Overview of crisisrooms. Crisisrooms: Towards a global network. Pawlak, P., ve AndreaRicci, ed. CrisisRooms: Towards a Global Network? Fransa: EU Institute for Security Studies, 179-186.

Nakip, M., Akdoğan, A., Çelik, A., Uzay Ş. ve İlkay, M.S. (2001). Kriz. Açıklamalı işletme Terimleri Sözlüğü, Literatür Yayıncılık, İstanbul, s. 115 
Ritchie, B. W., Bentley, G., Koruth, T., \& Wang, J. (2011). Proactive crisis planning: Lessons for the accommodation industry. Scandinavian Journal of Hospitality and Tourism, 11(3), 367-386.

Smith, D.G. (2006). Introduction to Crisis and Emergency Risk Communication. Presented in The Central Colorado Area Health Education Center Conference held in Ft. Collins in May 2006.

Tekin, Ö. F. (2016). Kriz Yönetimi ve Kamu Yönetimi İçin Önemi. Selçuk Üniversitesi Sosyal Bilimler Meslek Yüksek Okulu Dergisi, 18(2), 119-135.

Yılmaz, A. Y., Bozkurt, Y. B., \& Akdeniz, U. B. Kurumsal Yapı ve İşleyişiyle ABD'de Kriz Yönetimi. Anadolu Üniversitesi Sosyal Bilimler Dergisi, 14(1), 59-72.

Yılmaz, S. ve Gül, H.(2017) The Center of Crisis Management and Situation Room. International Relations and Diplomacy 6, no. 11. doi: International Relations and Diplomacy, (December 2017), Vol. 5, No. 12, 742-752.

URL 1: https://www.msb.se/en/About-MSB/Crisis-Management-in-Sweden/ sitesinden 7 Mart 2019 tarihinde erişilmiştir. 